\title{
Benjamin Engels \\ Roman Basket Urns as Elements in a Transmaterial Design System
}

\begin{abstract}
The paradigm of material hierarchies is increasingly losing importance in the research on transmaterial references in artefact design. Instead, the independent aesthetic agenda of the respective objects is usually emphasised. This paper examines what constitutes this specific aesthetic, how it is produced and how it can be further differentiated by using the example of a group of stone urns whose surface design refers to the texture of wickerwork. In the analysis, the notion of linear dependencies is replaced by the concept of a design system consisting of genre-immanent and intermedial references. This approach allows clear differentiation of phenomena within this group, which has so far been regarded as homogeneous. The results are significant for interpretation of the urns within the context of ancient funerary culture, but they also provide general information on the mechanisms of ancient artefact design.
\end{abstract}

The aim of this paper is to investigate a group of urns from the Roman Imperial period, whose unifying feature is a surface textured in the manner of wickerwork and which have not yet been comprehensively examined in any existing study. The intention is to use a clearly defined group of artefacts to demonstrate the potential of a perspective on transmaterial design that discards the idea of clear directionalities between an authentic material prototype and a replica (and, with this, an 'origin' in a temporal sense), and embraces the notion of a design network featuring complex interdependencies ${ }^{1}$. This desideratum results directly from the observation that previous studies of this material lack an engagement with current theoretical considerations of the reciprocal relationship between (cultural) texts ('inter-/trans-textuality'2), images ('inter-/transpictoriality'3) and media in general ('inter-/transmediality'). All these essentially structuralist concepts share an understanding of cultural expressions as parts of complex systems of (all) other cultural expressions. With the associated recognition of an independent aesthetic agenda of the respective products $^{5}$, the narrow interpretative focus on a hierarchical sequence of recognisable references (for example, in the sense of imitation) is likewise called into question ${ }^{6}$.

More recently, this concept has also been applied to materiality ${ }^{7}$. This new approach owes its appeal to the fact that formal and above all material transfers were long considered aesthetically inappropriate in the tradition of $19^{\text {th }}$ century art theory and according to the principle of 'truth to material's. Especially in archaeology, the term 'skeuomorph' was established to describe such linear material transfers. Henry Colley March and Alfred C. Haddon first introduced this term as a neologism. For them it represented a mode of the ornamental, which, in their explicitly evolutionist

1 See Wolf 2016, 105, for a similar conceptualisation of 'transmateriality' as a 'neutral term that allows us to explore the artistic translation of materials into one another'.

2 For a summary with reference to antiquity, see Fullerton 1997, 437-440; Dorka Moreno 2019, $27-42$.

3 von Rosen 2011.

4 See Rajewsky 2002; Wirth 2013.

5 von Rosen 2011, 208: 'Qualität als originelle Differenz zu einem Vorbild oder einer Norm'. Also Strässle $(2014,15)$ postulates a distinct aesthetic value that is 'weder dem imitierten noch dem imitierenden Material zuschreibbar'.

6 See Fullerton $(1997,440)$, who pleads for an 'intertextual approach' that centres 'the interpretation on the relationships themselves while avoiding the a priori judgements inherent to concepts like influence and imitation'.

7 Strässle 2014, 12-16; Wabersich 2014; Wolf 2016; 2019, 93 f.

8 See the contribution by Haug - Hielscher, this volume. However, Gottfried Semper, for example, also emphasises the aesthetically pleasing aspects of creative imitation: 'Aber nochmals bewundern wir den hellenischen Geist, - mit welchem Takte er den stofflichen Bedingungen des Töpferthones gerecht zu sein verstand, indem er die herkömmlichen Typen in den wahren Töpferstil übersetzte' (Semper 1863, 113).

Ә Open Access. (C) 2022 Benjamin Engels, published by De Gruyter. (cc) BY-NC-ND This work is licensed under the Creative Commons Attribution-NonCommercial-NoDerivatives 4.0 International License.

https://doi.org/10.1515/9783110764734-014 
views, referred to an origin in terms of the technically conditioned surface textures of a prototype $^{9}$ made of another, usually organic, material ${ }^{10}$. A shift in meaning was then brought about by Michael Vickers and David Gill, who published extensively on skeuomorphism in Greek (and, less frequently, Roman) pottery. They followed the clear agenda of a formal precedence of metal and glass vessels over clay vessels and combined this with a resolutely economic interpretation based on the idea that the imitation should be considered less valuable yet more affordable than the original ${ }^{11}$. Only recently have a growing number of studies focussed on the aesthetic effects of transmaterial references, particularly in ancient pottery ${ }^{12}$.

'Basket urns' differ in several ways from the phenomena observed in pottery. For one, they refer to a (supposedly) inferior material rather than a higher quality one. Economically oriented hypotheses based on material hierarchies are therefore not at issue here, or if so, only in the sense of 'upgrading'. Second, the fact that possible 'real' prototypes are made of organic material also means that we are even less informed about their appearance and formal variance than, for example, in the case of the metal vessels that are discussed as prototypes for ceramic vessels. Third, unlike with metal, glass and ceramic vessels, the change of material is accompanied by a significant change in function ${ }^{13}$. Fortunately, the phenomenon as a whole is also much more limited and therefore suitable for detailed differentiation. That such an approach is necessary is demonstrated by the fact that although the urns can be clearly distinguished chronologically, regionally and in terms of their design, in literature, they are unanimously described as a coherent phenomenon with a uniform meaning. Moreover, the very terminology used to describe the phenomenon reveals the prevailing idea of a clear link between a model and its replica ${ }^{14}$, which should be thoroughly reconsidered.

In methodological terms, attempts have already been made to generally categorise different modes of intermaterial design. Thomas Strässle, for example, proposed the modes of 'Materialinteraktion', 'Materialtransfer' and 'Materialinterferenz' ${ }^{15}$. These categories are certainly helpful for a large-scale structuring of various phenomena within the material culture of a particular cultural context ${ }^{16}$. However, they are not suitable for a more granular subdivision of individual phenomena such as the present one, as the urns would all fall into Strässle's category of 'Materialtransfer'. It is precisely this more nuanced analysis, however, that is a necessary foundation for identification of a synchronous differentiation or a historical development of the material. Therefore, an initially inductively oriented phenomenological description of the objects seems more promising. The analysis will then explore the artistic means by which the urns are visually approximated to a prototype

9 Henceforth, the term 'prototype' is used deliberately without specifying its status as a concept or material thing. 10 Colley March 1890, 172-178; Haddon 1895, 75-117; cf. Donohue 2005, 81 n. 182. However, the concept of baskets as prototypes for ceramics can be found earlier, e. g., in Semper 1863, 33-37; cf. Zimmermann 1998, 4; Donohue 2005 , $76 \mathrm{f}$. 11 Representative for many other publications: see Vickers 1985; 1999; Gill - Vickers 1990. For a critical evaluation, see Zimmermann 1998, 2; Wabersich 2014, 209-211; Grüner 2017, 29 f.

12 Zimmermann 1998; Wabersich 2014; Blitz 2015; Grüner 2017 and Flecker, this volume.

13 Unless we assume that urns made of wickerwork existed. See below for a more detailed discussion of this problem. 14 Alexander 1938, 52 ('made to look like a wicker basket'; 'replicas'); Toynbee 1971, 255 ('appear to counterfeit wicker baskets'); Buora 1982, 189 ('Anche nei minimi dettagli e chiara la volonta di riprodurre degli autentici recipienti in vimini.'); Bertacchi 1982, 220 ('decorata in modo da simulare un paniere di vimini'); Monacchi 1996, 971 ('fedele imitazione degli esemplari reali anche nei dettagli'); Feugère 2001, 24 ('reproduit tres fidelement'); Cullin-Mingaud 2010, 92 ('reproduisent très rigoureusement des cistes en vannerie'); Abbondanza 2019, 94 ('riproducono con esattezza gli intrecci dei giunchi di vimini').

15 Strässle 2014, 13-16. Strässle draws directly on Rajewsky’s (2002, 15-19) concepts of 'Medienkombination' (media combination), 'Medienwechsel' (media exchange) and 'intermediale Bezüge' (intermedia references). In a similar deductive approach, Zimmermann (1998, 9) used terms from the field of rhetoric (interpretatio, imitatio, aemulatio) to describe the relationship between metal and clay vessels. This approach is not convincing, because apart from the anachronism that Zimmermann does not deal with 'Roman' material culture, she mainly describes the transfer of forms existing simultaneously, rather than a retrospective adaption. Furthermore, different modes of formal transfer are likely to apply to ceramics and sculpture in general: see, e. g., Rolley 2001.

16 Cf. Flecker, this volume. 


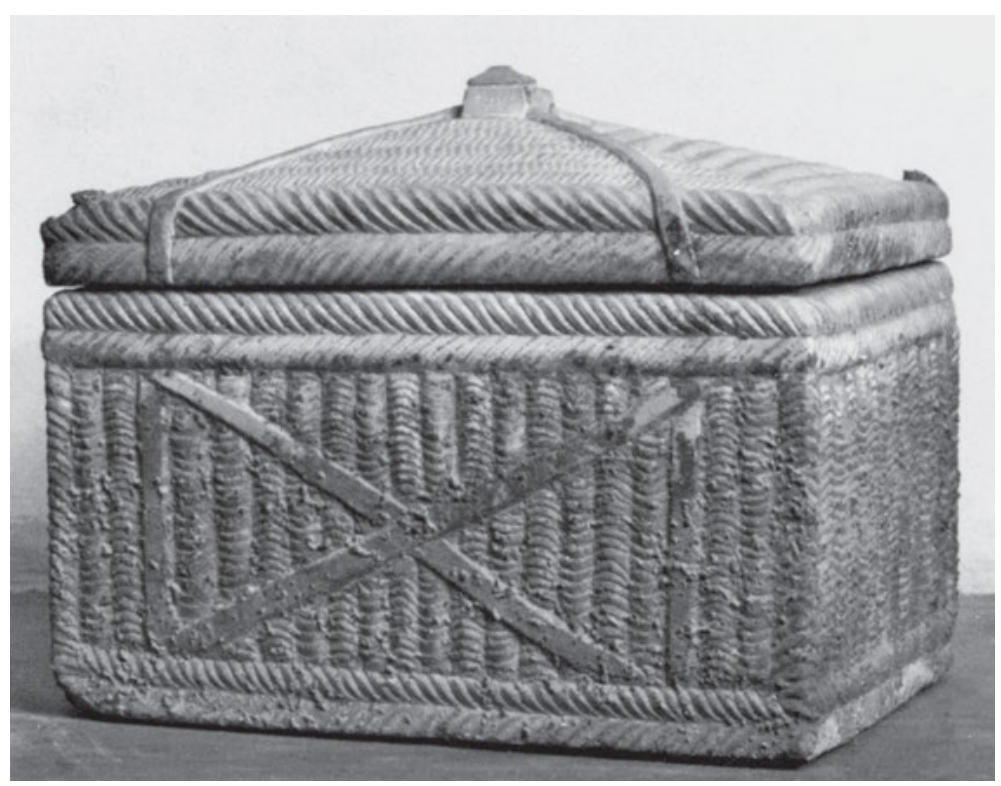

Fig. 1: Basket urn, marble, $24.0 \times$ $30.0 \times 23.3 \mathrm{~cm}$; Naples, Museo Archeologico Nazionale, s.n. (here: no. 4).

and, at the same time, identify the structural aspects by which this proximity is, in turn, mitigated or irritated. This enables further characterisation of the prototypes to which the respective object refers in its design, and analysis of how they relate to one another in a complex design system. On this basis, we can finally ask which chronological, functional or semantic aspects are associated with the different design modes.

\section{Form}

The known cases of urns with a wickerwork surface form two apparently independent clusters ${ }^{17}$ : a small one from Rome and a much larger one consisting of several workshops in the upper Adriatic/southeast Alpine region, with a major concentration in Aquileia (hereafter referred to as the 'Aquileian cluster', for the sake of simplicity) ${ }^{18}$. The list provided in the appendix contains all 24 known specimens, as well as 19 'pseudo-urns' ${ }^{19}$. Since we are primarily interested in the visual phenomenon here, and the two groups cannot be fundamentally distinguished solely on the basis of their surface design ${ }^{20}$, they are analysed together rather than separately. Most of the pieces have a cylindrical shape and only three of them are rectangular (nos. 4, 5 and 43; Fig. 1).

Apart from these general differences in form and origin, the basic structure of most of the pieces shows remarkable similarities, both in terms of the general composition and the weaving technique depicted. The horizontal division of the basket body is achieved by means of single, double or multiple layers of braided bands (nos. 28, 29 and 30; Figs. 2 and 3), which always form a base and a top 'moulding'. A horizontal profile running around the centre further divides the walls of almost all the cylindrical pieces, with the exception of urn no. 1. This profile is once more either designed as a braided band (e. g., nos. 2 and 10; Fig. 4), or as a wide cuff, and is framed by braided bands that are undecorated (nos. 7 and 28; Fig. 2) or decorated with an ornamental pattern (nos. 6, 9, 23,

17 Sinn 1987, 15.

18 The urns from Rome are made from marble, those of the Aquileian cluster mostly from limestone.

19 The massive 'pseudo-urns' served either as grave markers (cippi) (Buora 1982, 192 f.; Verzár Bass 1998, 168) or were part of the sculptural decoration of monumental tombs: see Miglbauer 1994.

20 Compare nos. 28 and 29, for instance. 


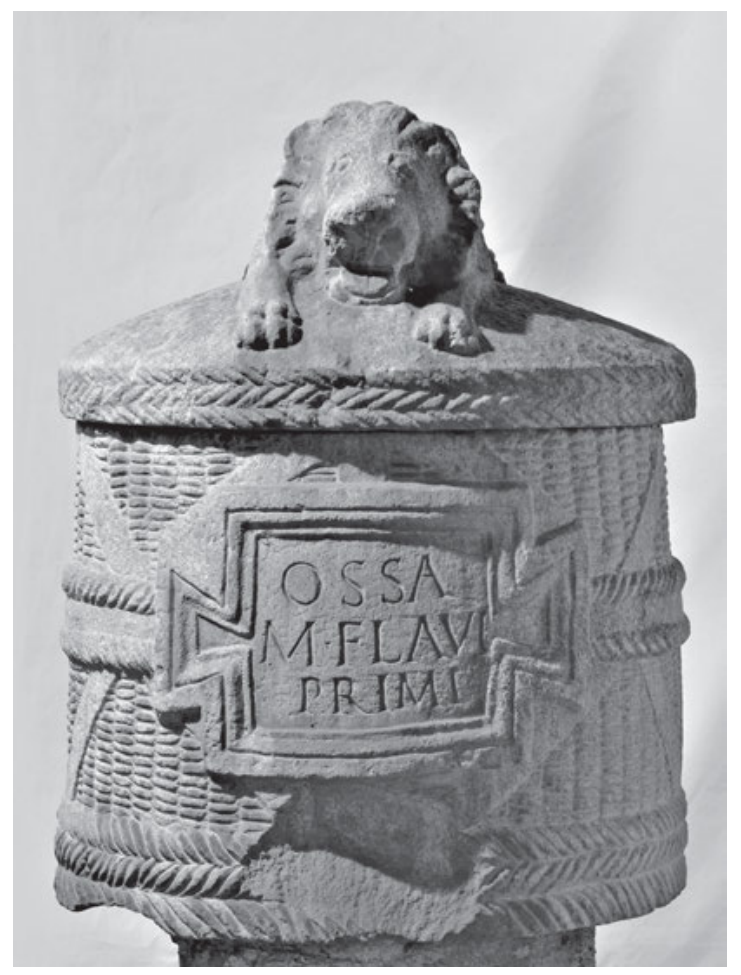

Fig. 2: Basket urn, limestone, H $56.0 \mathrm{~cm}$, D $45.0 \mathrm{~cm}$; Aquileia, Museo Archeologico, inv. 854 (here: no. 28).

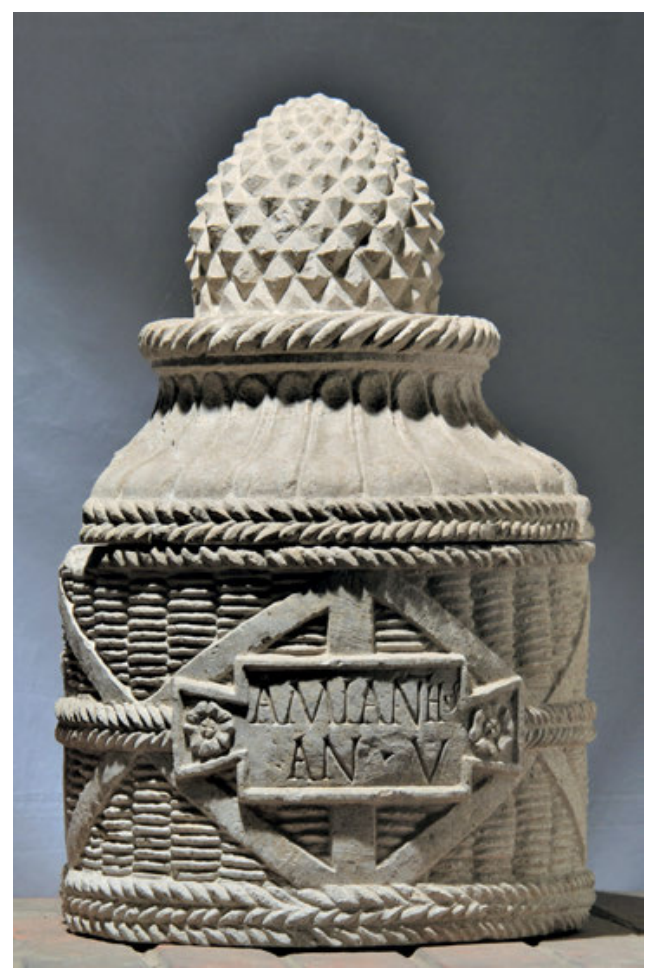

Fig. 3: Basket urn, limestone, H $45.0 \mathrm{~cm}$, D $30.0 \mathrm{~cm}$; Aquileia, Museo Archeologico, s.n. (here: no. 30).

29, 31, 32[?] and 40). The actual wickerwork is always organised in vertical registers, filled with horizontal ribs ${ }^{21}$. These ribs, which indicate the individual willow rods, are either flush with one another or slightly offset so that each rib ends just between the two adjacent ones (e. g., no. 30; Fig. 3$)^{22}$. In all cases, therefore, an extraordinarily dense weave is represented, which has no gaps and does not reveal the vertical stakes. Another common motif that can be found in urn no. 4 and in all the pieces from the Aquileian cluster, is the pattern of horizontal and diagonally crossing flat bands which further structure the body of the urns and which apparently represent lacings to stabilise the wickerwork ${ }^{23}$.

Apart from these connecting elements, which enable a systematic comparison of the objects in the first place, there are clear differences on various levels, and these can also be described in terms of different degrees of proximity to or divergence from basket prototypes. This applies, on the one hand, to the motivic coherence of the objects as 'baskets' and, on the other hand, to their respective surface texturing and their relationship to the material depicted, i. e., willow or rushes. In the examples from Rome, every visible part of the surface - both the body and the lid - is textured as wickerwork. The knobs of the lids, in particular, are designed in varying detail and thus give the impression of antiquarian exactitude. For example, urn no. 2 displays a tassel made of textile or leather and no. 4 a kind of clasp made of bone that is known from the archaeological record ${ }^{24}$. In

21 There are, however, two exceptions: according to the Canina drawing (Fig. 9), the wickerwork of no. 3 seems to have been represented by diagonal grooves instead of vertical registers. And in no. 10 the horizontal willow rods fill the spaces between the cross bracings without further subdivision.

22 Since Buora (1982) illustrates the urns from Aquileia exclusively in schematic drawings, this distinction cannot be made for all pieces.

23 The material of these lacings is undetermined. Cullin-Mingaud (2010, 59) suggests that it is leather, Bertacchi (1982, 221) that it is willow bark.

24 Feugère 2001; Gostenčnik 2004. 

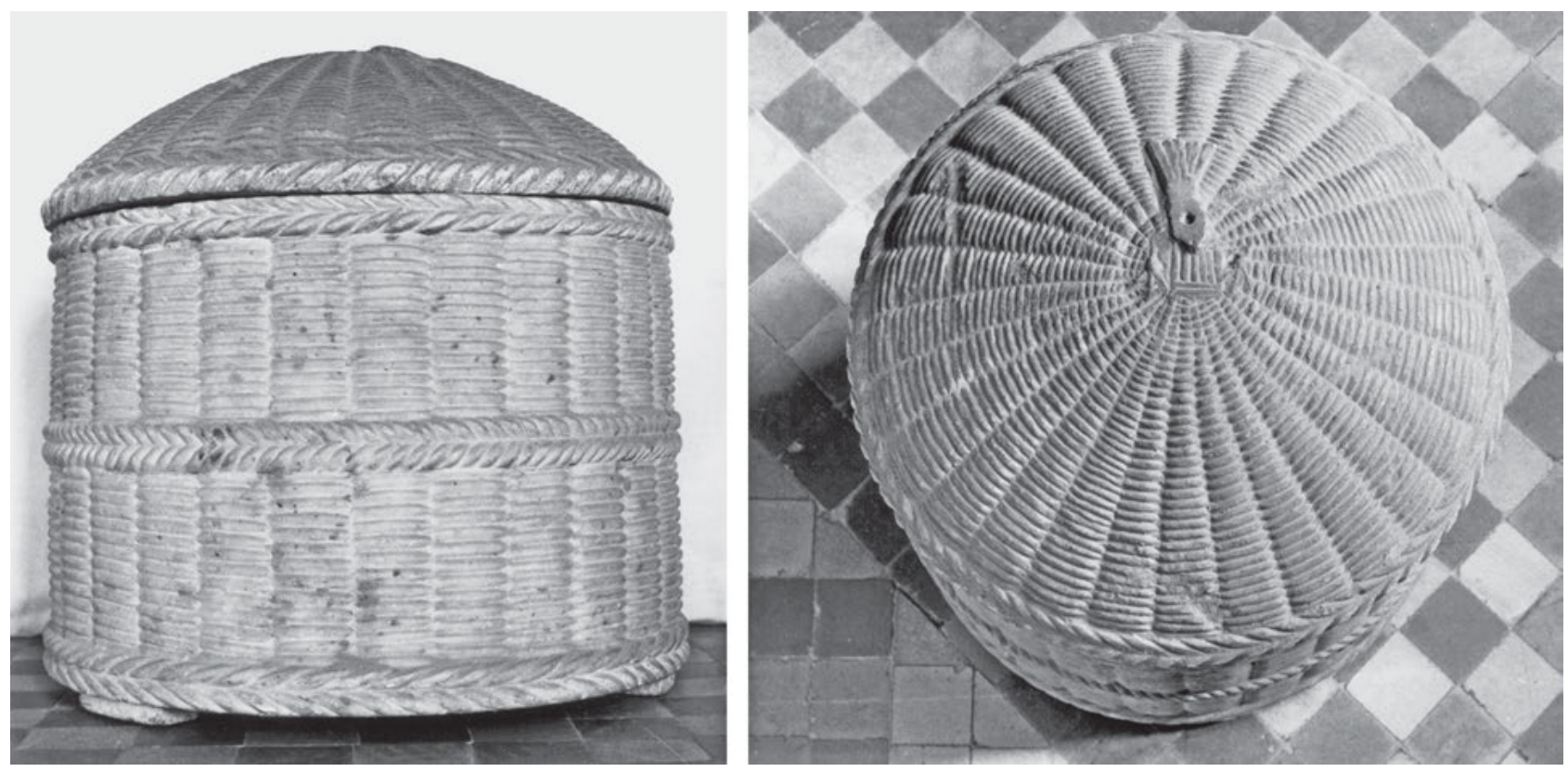

urn no. 1 (Fig. 5), the centre of the upper side is covered by a circular, flat, unornamented disc with a drilled hole in the middle, which most likely represents a bone disc that was used to hold the radial stakes of the lid in place ${ }^{25}$. What is particularly noticeable about this lid is that the sculptor has deliberately incorporated many small weaving faults ${ }^{26}$. The wickerwork is not parallel in places, and individual ribs converge instead of running straight up against the next vertical segment. It is also striking that the upper 'moulding' changes its direction at two points, although it would not need to do so from a weaving (and even more so from a sculptural) perspective. Altogether, in these examples, the intention to create an (almost) unbroken pictorial reference to wicker baskets is already apparent at the motivic level ${ }^{27}$. Furthermore, individual elements of the representation find almost exact correspondences in the components of actual wicker baskets known from the archaeological record.

For the Aquileian cluster, this principle of coherence is in no case proven with certainty, although it cannot be ruled out entirely for the fragmented pieces. The most obvious visually disturbing factors here are the design of the lids and the ubiquitous use of tabulae with or without inscriptions. Significantly, the only specimen in the Aquileian cluster whose lid is textured as wickerwork shows a tabula on its body (no. 22; Fig. 6). In other cases, the walls are coherently designed as a basket surface, but the lids deviate, for example, either by not being decorated at all (no. 6) - and thus conforming to the standard for urns in Aquileia - or by carrying crouching dogs or lions, thus blatantly contradicting the consistent overall impression of a basket (no. 8). A particularly deviant and unusual case is urn no. 30 , with its lid that terminates in a pinecone, a design known from funerary altars and the roofs of monumental tombs (Fig. 3) ${ }^{28}$. Finally, there are three loosely related individual cases. The wickerwork surface of no. 39 additionally features the representation of a transitus in relief, thus counteracting a consistent reading as a representation of a basket (Fig. 7). In nos. 40 and 41 (Fig. 8), the wickerwork texturing of the surface has been dispensed with completely, so that at first glance there seems to be no reference to baskets at all. The
Fig. 4: Basket urn, marble, $\mathrm{H} 22.5 \mathrm{~cm}$, D $32.0 \mathrm{~cm}$; Rome, Musei Vaticani, Galleria Lapidaria, inv. 9237 (here: no. 2).

25 See Gostenčnik 2000a, 59; 1997 for examples made of bone without reference to no. 1, which provides important evidence for Gostenčnik's interpretation of these bone discs.

26 See Zanker 2020, 267.

27 Only no. 1 subtly deviates from this rule (see below).

28 For the connection with tomb architecture, see Bertacchi 1982, 222; Buora 1982, 194. 


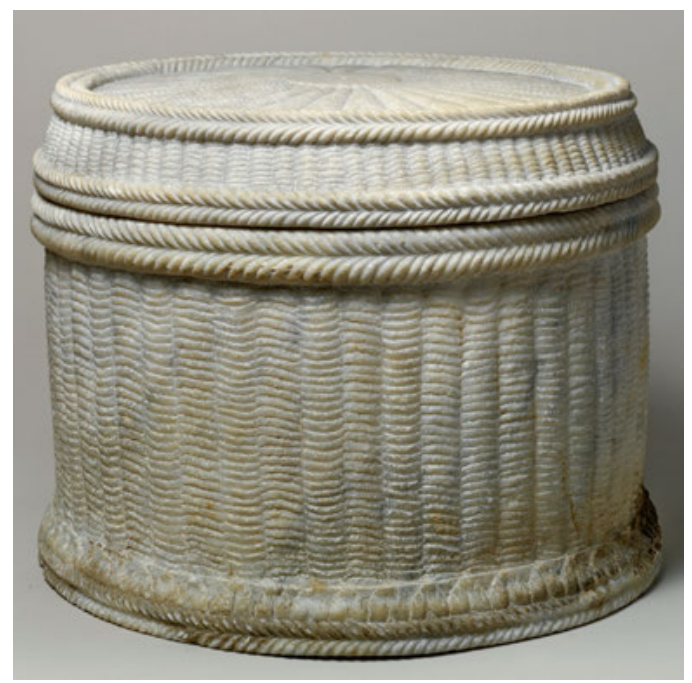

Fig. 5: Basket urn, marble, $\mathrm{H} 24.6 \mathrm{~cm}, \mathrm{D} 31.6 \mathrm{~cm}$; New York, Metropolitan Museum of Art, inv. 37.129 a, b (here: no. 1).

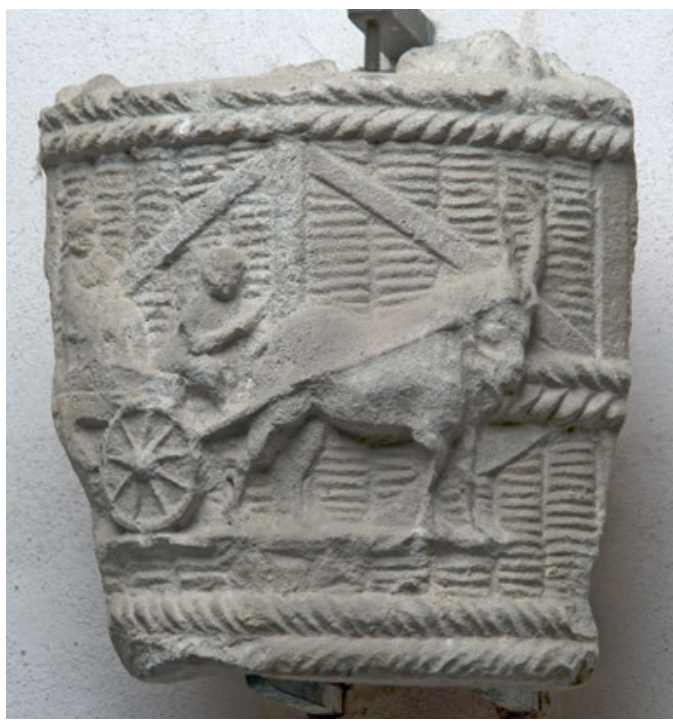

Fig. 7: Basket urn, limestone, H $25.0 \mathrm{~cm}, \mathrm{D} 30.0 \mathrm{~cm}$; Aquileia, Museo Archeologico, inv. 1576 (here: no. 39).

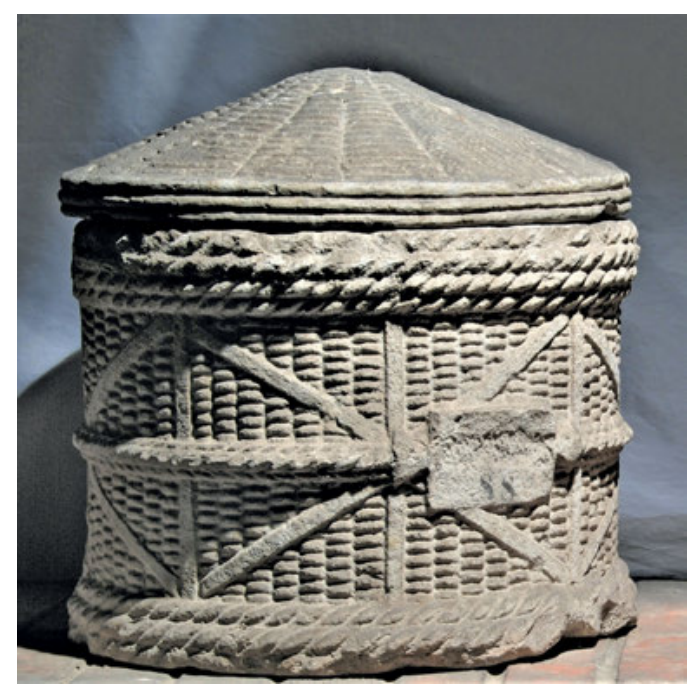

Fig. 6: Basket urn, limestone, $\mathrm{H} 41.0 \mathrm{~cm}, \mathrm{D} 44.0 \mathrm{~cm}$; Aquileia, Museo Archeologico, s. n. (here: no. 22).

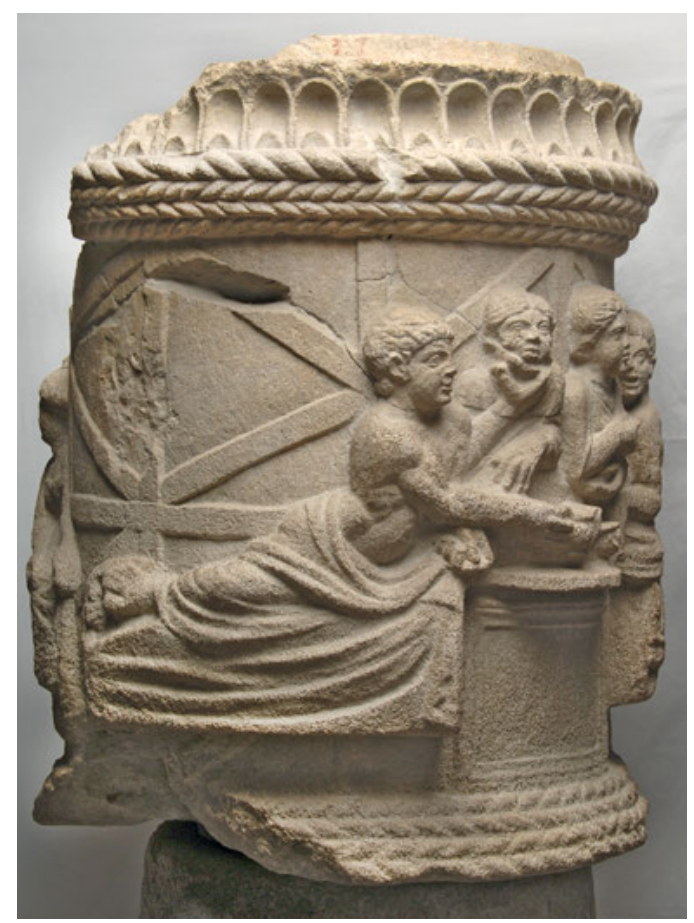

Fig. 8: Basket urn, limestone. $H 67.0 \mathrm{~cm}$, D $56.0 \mathrm{~cm}$; Aquileia, Museo Archeologico, inv. 317 (here: no. 41). 
appearance of urn no. 41, in particular, with its banquet scene in relief, is so far removed from real wicker baskets that Valnea Scrinari has suggested that it represents an outdoor banquet, with a wooden construction for a tent in the background ${ }^{29}$. In fact, a direct comparison with the other pieces shows that the horizontal and diagonal 'beams' are indeed lacings, as described above ${ }^{30}$. Thus, while there are certainly elements here that create a link between the urn and baskets, these quite literally recede into the background.

As well as these motivic features (some of which are clearly distinguishable), the stylistic implementation can also be compared ${ }^{31}$. Of particular interest here is whether and to what extent the surfaces are textured in a way that refers specifically to the materials represented. Differentiations in this respect can be compared particularly well based on representations of the horizontal weave structure and the lacing. Urn no. 1 in particular (along with nos. 4, 5 and, to a lesser extent, 23) is characterised by an uneven and therefore lively arrangement of the horizontal ribs in rather flat relief, which differ clearly in diameter and plastic volume from the stakes braided into profiles. The intention seems to have been to make a distinction in the representation of the wickerwork between the thicker stakes, which give stability to the basket construction and the more delicate willow rods wound around them. This differentiation in the representation of the material is particularly evident in the lacings of no. 4, which are organically placed around the edge of the lid and overlap on the basket wall in a technically plausible manner ${ }^{32}$.

This overall naturalistic mode of design can be clearly distinguished from cases in which the differentiation of willow rods is not applied. For example, the horizontal ribs of urn no. 3 all look the same, and their plastic volume does not differ from the rods in the braided profiles. This also applies to almost all urns in the Aquileian cluster and can, in turn, be paralleled there with the rendering of the lacings, which usually appear as sharp-edged, stiff-looking bands on top of the wickerwork that do not overlap or otherwise refer to one another (e. g., no. 22; Fig. 6). Of course, this stylistic mode also evokes the impression of an exact reproduction of a wicker basket, except it is not achieved via a naturalistic differentiation of material qualities, but rather by a realisation of the characteristic rhythmic surface pattern resulting from the technique of basket weaving ${ }^{33}$.

\section{Chronology}

An evident question is whether these formal differences are chronologically sequenced. However, dating these pieces is rather difficult, since in most cases there are no datable contexts, and stylistic references are rare due to a lack of links to better-documented material. There are, however, some clues that provide a loose chronological framework.

In the case of Rome, the production of these urns seems to be limited to the Early Imperial period $^{34}$. There are two concrete indications of this: first, the presumed context of urn no. 3 (Fig. 9), which is usually associated with the Tomb of Eurysaces and could therefore date to the Late Repub-

29 Scrinari 1972, $106 \mathrm{f}$.

30 Maionica 1910, 48; Buora 1982, $191 \mathrm{f}$.

31 The closely related criterion of 'quality' (which could be brought into play for the Aquileian cluster in particular) is deliberately excluded here, as the focus is more on the visual appearance of the objects and less on their production conditions.

32 A polychrome rendering, which could further enhance the lifelike effect, has not been documented in any of the cases, but has been observed in other urns from Rome (Sinn 1987, 12). A basket representation from the Domus Tiberiana which belongs to a sculpture has a differentiated painting and gilding (Abbondanza 2019, 93).

33 See Bertacchi 1982, 220: 'I supporti verticali dell'intrecciatura sono larghi e piatti, ma non si vedono se non fnella loro sequenza perché sono completamente ricoperti dal fitto intreccio orizzontale del vimine sottile; questo e reso con estrema attenzione in modo da rappresentare in maniera realistica l'in-treccio, con lo sfalsamento delle linee, mentre il vimine in sé e trattato a risalto spigolato, in maniera innaturale.'

34 See Sinn 1987, 62, without concrete arguments. 
Fig. 9: Drawing of Basket urn by Luigi Canina; Rome, from Porta Maggiore, today lost (here: no. 3).
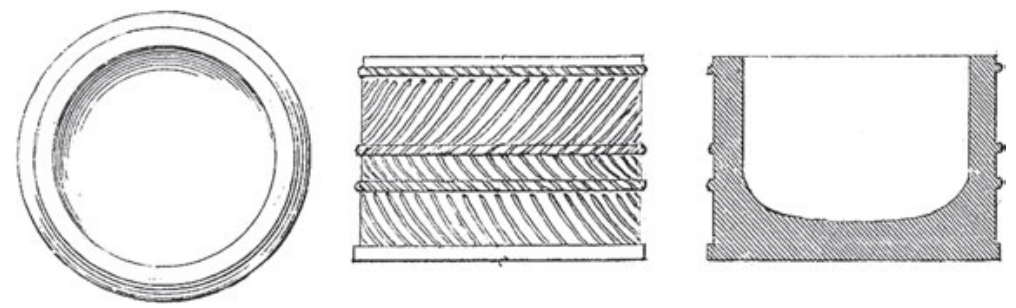

lic or Early Augustan period ${ }^{35}$. However, it must be pointed out that the urn itself was found in a secondary context near the grave and that the attribution is based on a complex chain of evidence, which will be further discussed below ${ }^{36}$. Second, urn no. 1 is often dated to the Augustan period, probably because of its high-quality workmanship and naturalistic style ${ }^{37}$. This dating is also supported by the design of the leaf cymatium running around the foot profile, which has not yet been considered in the discussion ${ }^{38}$. The same dating can be assumed for nos. 4 and 5, which are basket chests, as they are connected stylistically to no. 1 , which can be recognised in the characteristically curved ribs of the wickerwork that are bent alternately upwards and downwards ${ }^{39}$.

In the case of Aquileia, the phenomenon seems to be mainly limited to the $1^{\text {st }}$ century A.D. ${ }^{40}$. Here again, there is little concrete evidence for dating. The name of the deceased mentioned on urn no. 30, for example, points prosopographically to the $1^{\text {st }}$ century A.D. ${ }^{41}$. The inscription on no. 23 can possibly be dated to the beginning of the $2^{\text {nd }}$ century A.D. on the basis of the letter forms ${ }^{42}$, and no. 41 is dated by Scrinari to the end of the $1^{\text {st }}$ century B.C., based on a stylistic analysis of the relief decoration ${ }^{43}$. Both Maurzio Buora and Luisa Bertacchi assume that there is a succession of urns and 'pseudo-urns' - albeit each with a different group at the beginning. While Bertacchi argues for the primacy of 'pseudo-urns', citing the development of purely commemorative grave altars into forms with integrated ossuaries as an analogy ${ }^{44}$, Buora contends that the 'pseudo-urns' imitate stone urns (which, in turn, imitate wickerwork urns) ${ }^{45}$. This argument in particular reveals very clearly the concept of a directed and chronologically progressive imitation process, which almost inevitably leads to such sequences. Ultimately, both models prove to be intuitive, as there are no

35 For a discussion of the tomb's date, see Petersen 2003, 240 n. 46; Jones 2018, 64 n. 5.

36 These concerns are shared by Ciancio Rossetto $(1973,30)$.

37 Waywell 1986, 106 ('dating perhaps to the early Imperial period'); Sinn 1987, 62 (Early Imperial); Picón 2007, 488 no. 422 (Augustan, c. 10 B.C. - A.D. 10); Zanker 2020, 267 (Early Imperial, c. 10 B.C. - A.D. 10).

Occasionally, the date is more general: see D’Ambra 1989, 399 n. 5 ('It may date to the first or second century A.D.'). 38 Comparable leaf forms with a delicate plant texture can be found in the Basilica Aemilia (Lipps 2011, 79 Fig. 55), for example, or on Early Imperial putealia (Golda 1997, 87 cat. no. 24 Pl. 65, 1), and on Augustan urns with more reliable stylistic dating criteria (Sinn 1987, 94 f. no. 15 Pl. 7). The 'vegetabilisation' of the cyma's leaves (which is only hinted at here) is a characteristic of Flavian architectural ornament (see Wegner 1957, 52-54; Ganzert 1983, 196; Pfanner 1983, 24), but it differs in the absence of light/dark contrasts caused by the holes drilled in such Flavian ornamentation.

39 Zanker $(2020,267)$ recently suggested that no. 1 and no. 2 also come from the same workshop. Given the stylistic differences described above, this does not seem very plausible.

40 Scrinari 1972, 105-107 nos. 315-317; Buora 1982, 193; Ortalli 2005, 262; more carefully, Miglbauer 1994, 157 (1 $1^{\text {st }}-2^{\text {nd }}$ centuries A.D.).

41 Bertacchi 1982, 225.

42 Maionica 1895, 31f. no. 20; Buora 1982, 193. 197. According to Buora, this is one of the latest basket urns from Aquileia.

43 Scrinari 1972, 106 f.; Buora $(1982,196)$ suggests a later date, during the first half of the $1^{\text {st }}$ century A.D., based on the shape of the amphora depicted in the relief. However, considering the vague depiction, his identification with the type Dressel 6B, on which the date is based, is not imperative. The amphora could also belong to the type Dressel 6A or even Lamboglia 2, which would again indicate a date from the Late Republican period: see Bezeczky 2013, 114 f. 120. 44 Bertacchi 1982, 223.

45 Buora 1982, 193: 'Sembra evidente che le pseudourne nascano per imitazione delle urne a cista [...]'. 
formal indications in the material from Aquileia that suggest a non-concurrence of urns and 'pseudo-urns' in any way.

However, it is remarkable that the other examples from Pannonia and Noricum are all dated to a later period, namely during the $2^{\text {nd }}$ and $3^{\text {rd }}$ century A.D. ${ }^{46}$. The obvious stylistic (and, for no. 10 , also motivic) differences in these cases could therefore also have a chronological explanation. Furthermore, these dates suggest that the wide 'cuffs' placed around the body of the vessel, which are found in all these pieces but also in some from Aquileia, might be a late phenomenon ${ }^{47}$. For other formal aspects, however, the scarce chronological data does not provide any sequencing. On the contrary, both in Aquileia and perhaps also in Rome, in the Late Republic or Early Imperial period, rather different manifestations of the phenomenon appear to exist simultaneously, and heavily reduced adaptations of the basket motif (as in nos. 40, 41 and, if the dating is correct, 3) are thus found among the earliest pieces.

\section{Use}

As opposed to some claims in literature ${ }^{48}$, this type of urn was not that common, at least in Rome $^{49}$. In the Aquileian cluster, this statement seems to be true for the decorated urns, and yet most of the urns were still undecorated ${ }^{50}$. While there can be no doubt that the pieces from Aquileia were used as urns or cippi, as demonstrated by the inscriptions or the combination with characteristic urn lids (nos. 23-30), this is not necessarily the case for the pieces from Rome. Although they are consistently referred to as such in the literature ${ }^{51}$, and their shape, size and affordance render this probable, there are nevertheless no formal links to other urns that would allow for an immediate visual identification. This 'retarding moment' is thus obviously a deliberate feature of the design of the pieces.

\section{Interpretive Approaches}

There are two major lines of interpretation in the literature for these pieces: on the one hand, a wide array of socio-historical approaches that focus on the identity and sometimes even biography of the individuals buried in these urns and, on the other hand, eschatological considerations that are mainly concerned with a symbolic or metaphoric reading. The socio-historical interpretations all start with a concrete identification of the baskets as either cistae myticae, wool baskets or bread baskets. Identification as a cista mystica is generally based on convincing iconographical comparisons with cistae mysticae in other media ${ }^{52}$. The urn is then connected with the cult of Bacchus and/or Ceres - either generally ${ }^{53}$ or via a specific connection with the deceased as a mystes ${ }^{54}$.

46 No. 9: first half of the $2^{\text {nd }}$ century A.D. (Piccottini 1996, 79); no. 7: $2^{\text {nd }}$ century A.D.; no. 6: Middle Imperial period (both Miglbauer 1994, 157); no. 10: $3^{\text {rd }}$ century A.D. (Miglbauer 1994, 157) or second half of the $2^{\text {nd }}-3^{\text {rd }}$ centuries A.D. (Kremer 2001, 145).

47 This observation increases the doubts concerning the affiliation of no. 3 with the Tomb of the Eurysaces.

48 Cormack 1996, 202 Fig. 153 ('often associated with female burials'); Petersen 2003, 234 ('common type'); Met Collection Online 2020, ('popular').

49 Picón 2007, 488 ('unusual type'). Cf., for instance, the small number of these pieces in Sinn 1987.

50 For example, all decorated urns from Aquileia published by Scrinari (1972) are basket urns.

51 The only exception is Amelung (1903, $218 \mathrm{f}$.), who considered no. 2 to be a votive.

52 Krauskopf 2005; Abbondanza 2019, 97 f. Altmann (1905, 238 f.) and Sinn (1987, 63) reject this identification because the urns lack the snakes that are almost obligatory for representations of cistae mysticae in images.

53 Platner et al. 1834, 37; Buora 1982, 194; Gostenčnik 2000a, 72 f.

54 Amelung 1903, 218f.; Alexander 1938, 52; Ortalli 2005, 262. 
In the literature on no. 1 in particular, the interpretation of the urn as a wool basket, relating to the female sphere and the qualities of the deceased as a virtuous, diligent Roman matron, is widely accepted $^{55}$. While the pieces from Rome lack inscriptions that could provide information about the identity of the deceased, the evidence from Aquileia clearly brings into question the exclusive validity of this interpretation: among the four urns with inscribed names, two were intended for male burials (nos. 28 and 40; Fig. 2) and one for a five-year-old boy (no. 30; Fig. 7) ${ }^{56}$.

The last two lines of interpretation share the idea of a biographical reference to the deceased person. This approach has been applied specifically to urn no. 3. In 1838, during the exploration of the nearby Late Republican Tomb of Eurysaces (a freedman who had made his fortune as a bakery entrepreneur), a fragmented block with the following inscription was found: 'Atistia was my wife; she lived as the best woman, the remains of whose body, which survive, are in this bread basket' ${ }^{57}$. Because of the thematic connection provided by the term 'bread basket' (panarium), the inscription was assigned to the tomb, although no clear architectural context could be confirmed ${ }^{58}$. The discovery of urn no. 3 in the vicinity (but not in the same archaeological context) then completed the puzzle, as it was identified as the urn of Atistia, the breadbasket mentioned in the inscription ${ }^{59}$. Apart from the fact that this individual explanation does not allow for consideration of the urns' design as a cultural phenomenon presupposing a supra-individual meaning, this interpretation has two major shortcomings. First, the idea that an inscription on the façade of the tomb includes the demonstrative pronoun $h o c$ to refer to an urn not visible from the outside is not very plausible ${ }^{60}$. Furthermore, bread baskets depicted in reliefs and paintings usually have open bowl-like shapes and are rather roughly woven ${ }^{61}$. Even from the Canina drawing (Fig. 9), we can be certain that these criteria do not apply to no. 3 at all. Altogether, we must conclude that there is really no substantial evidence linking the urn to this particular tomb ${ }^{62}$.

The eschatological interpretations follow two different paths. The first takes up the above-mentioned interpretation of no. 3 and suggests that all the extant pieces represent breadbaskets and symbolise food supply (and thus, well-being) for the afterlife $\mathrm{e}^{63}$. The second focuses on the semantics of the material represented and reads it as a metaphor for durability ${ }^{64}$. In fact, by visually denying ephemerality in favour of embodying stability and longevity, the design of the basket urns is compatible with claims of eternity that also appear in funeral epitaphs, for example ${ }^{65}$.

What both approaches have in common is that they regard the urns as imitations or replicas of real baskets. They are thus implicitly linked to an antiquarian perspective in which the basket urns are, above all, a source for ancient basketry, a trade whose products are otherwise scarcely

55 Verzár Bass 1985, 204; D’Ambra 1989, 399; Kleiner 1992, 107; Cormack 1996, 202; Picón 2007, 488; Met Collection Online 2020; Zanker 2020, 267.

56 See Gostenčnik 2000a, 72.

57 CIL I $^{2}$ 1206: fuit Atistia uxor mihei / femina opituma veixsit / quoius corporis reliquae / quod superant sunt in / hoc panario; translation by Jones 2018, 64.

58 See Petersen 2003, 231-235. For a complete discussion of the reconstruction arguments of the monument, see also Jones 2018, 64.

59 See Sinn 1987, 63; Kleiner 1992, 107; Petersen 2003, 234 and (more skeptically) 250 f.; Broekaert 2008, 205. Ciancio Rossetto (1973, 30 n. 90), however, did not make this connection explicitly.

60 More likely, though not entirely convincing, is the suggestion of a more complex, perhaps even comical allusion to the profession of Eurysaces or even the building as such: see Petersen 2003, 251.

61 Conveniently, the south frieze of the Tomb of Eurysaces features some typical examples: Petersen 2003, 233 Fig. 5. A similar bread basket can also be seen on the famous wall painting from the Casa delle Panettiere (VII 3,30) in Pompeii (Naples, Museo Archeologico Nazionale, inv. 9071; Fröhlich 1991, 236-241) and a (presumed) wicker bread basket matching this shape was found in Aquileia: see Gaitzsch 1986, 85 no. 18.

62 There are plenty of other graves in the area to which the urn may have belonged: see, e. g., Coates-Stephens 2004, $18-21$.

63 Toynbee 1971, 255; Bertacchi 1982, 220; Verzár Bass 1985, 204.

64 Buora 1982, 194. For Middle Geometric pottery ‘baskets’, see Brann 1962, 14f.; Haug 2018, 105 f.

65 Lattimore 1942, 165-168. 
preserved in the archaeological record ${ }^{66}$. This approach is sometimes extended by the idea that the stone urns reproduce functional predecessors made of real wickerwork ${ }^{67}$, which corresponds to the common conception of the skeuomorph as an 'object that displays its own genealogy'68. But can this undoubtedly intuitive connection between real baskets and basket urns be taken for granted? On the one hand, the constructive details of the basket urns from the city of Rome (which have been reproduced in detail) speak to the legitimacy of this approach. On the other hand, the formal homogeneity of most other examples shows that the objects are not likely to be direct replicas of individual baskets, but rather part of a centuries-long design tradition with a formal and iconographic 'Eigenlogik', which deserves further investigation.

\section{Synchronous and Diachronic Approaches to a Transmaterial Design System}

A detail of urn no. 1, thus far only briefly mentioned, can be instructive in this context: above the plaited foot profile runs a simple leaf cymatium, which is chiselled in conspicuously low relief on a plain ribbon (Fig. 5). There are two ways to read this detail, which is unique among all other examples. The most obvious is to take the object's evident naturalistic ambition seriously and to understand the cymatium as a component of a basket prototype, for example, in the form of a separately manufactured and attached bronze sheet. In this case, the urn would be a mimetic representation of a basket. A relief on an altar from Capri supports this reading, as it shows a cista mystica with the same type of cymatium (Fig. 10) ${ }^{69}$. However, the examples from Aquileia indicate that basket urns can be combined with design elements found also on other urns. Indeed, there are many Roman marble urns with similar cymatia ${ }^{70}$. The cymatium therefore establishes a visual connection to the genre of urns by adapting a characteristic design feature. It could then be understood as a 'fiction signal' that exposes the basket-like nature of the urn to the viewer, revealing it as a mimetic illu$\operatorname{sion}^{71}$.

Whether or not wicker baskets with such profiles actually existed is not, in principle, decisive for this effect. In any case, the design of this wicker basket - be it a real one or merely an allusion would have encompassed a transmedial reference to the design principles of urns and other richly decorated, round marble objects such as putealia ${ }^{72}$. To put it briefly, no. 1 is an urn designed to naturalistically resemble a basket, which in turn has design features characteristic of urns. It is obvious that this semiotic interplay could easily continue in an infinite loop ${ }^{73}$, and it is fair to assume that this oscillation was deliberately intended in the design of the urn. It should therefore be clear that in this case trying to establish a linear relationship between prototype and imitation is not worthwhile. Rather, we can only seek to determine the position of the object in a design network, without

66 Monacchi 1996, 971; Gostenčnik 2000a; Krauskopf 2005, 274; Broekaert 2008, 205; Cullin-Mingaud 2010, 92. On this notion in general, see Donohue 2005, 81: 'Such skeuomorphs can be used to reconstruct ephemeral artefacts that cannot be recovered archaeologically. Understood in this way, the skeuomorph functions to extend the archaeological record.'

67 Brusin 1929, 57; Buora 1982, 189. 194; Gostenčnik 2000a, 73; Liverani et al. 2010, 222.

68 Donohue 2005, 82.

69 Dräger 1994, 188 f. cat. no. 9 Pls. 76, 2. 77, 2.

70 They occur both in round (Sinn 1987, cat. nos. 13. 25. 51. 124. 554. 631) and rectangular examples (Sinn 1987, cat. no. 8. 9. 26. 31. 52. 303. 610).

71 The pleasure of unmasking an almost perfect illusion has its fixed place in ancient literary reflection on lifelike representations. The texts thereby explicitly refer to 'fiction signals' such as statue bases or inscriptions: see Wessels 2014. 72 Urns: Sinn 1987, 94 f. no. 15 Pl. 7; putealia: Golda 1997, 87 cat. no. 24 Pl. 65, 1.

73 The complexity also increases further. For example, braided profiles can be found on urns whose surface is not textured as wickerwork: Sinn 1987, 92 no. 6 Pl. 4 e. 114 no. 93 Pls. 26 c. d. 
Fig. 10: Representation of a cista mystica on an Early Imperial altar; Capri, Museo Diefenbach, s. n.

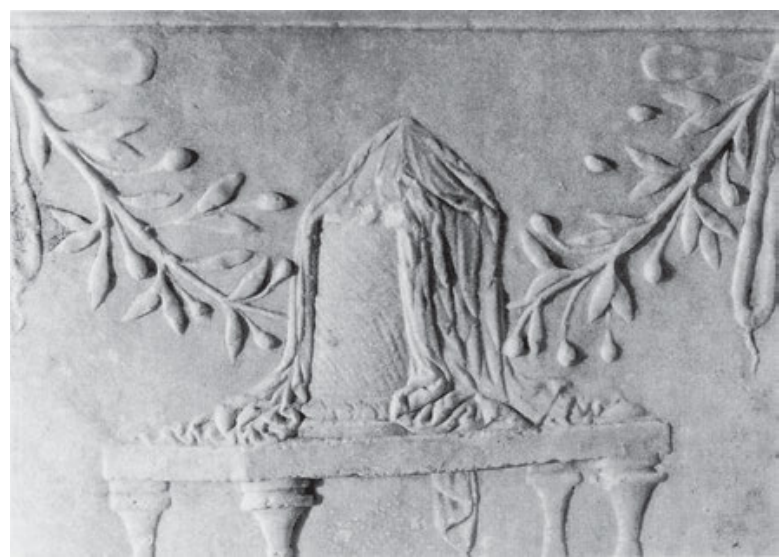

striving to trace its genesis in every detail. While the elaborate, complex design of no. 1 makes it is an isolated case, the other urns from Rome (except for no. 3) can be explained in similar terms. In their design, they are also evidently intended to create the impression of being lifelike replicas of wicker baskets, but they do not address or provoke this relationship in such a targeted way. Overall, this phenomenon is heterogeneous in formal details and confined to the Early Imperial period; it can thus be understood historically as a snapshot, without any discernible chronological depth.

The situation in the Aquileian cluster is quite different. Although it can also be observed here that the first basket urns were produced at an early date (perhaps even in the Late Republic), it continued steadily until at least the end of the $1^{\text {st }}$ century A.D. and had an even longer tradition in the Eastern Alps (perhaps extending into the $3^{\text {rd }}$ century A.D.). In addition to the much more distinct and consistent use of 'fiction signals' that establish a link to other types of urns within the design system, the diachronic formal unity of the group is particularly striking, especially with regard to the structure of the body surface and the composition of its tectonic elements. First of all, if the question of real basket prototypes is raised again (which the literature on these pieces explicitly presumes $)^{74}$, we would have to conclude that these baskets also remained formally unchanged over the centuries. Although this is not excluded in principle, it would do little to change the fact that the urns clearly form a typological series in and of themselves, i.e., they refer to other urns as much as they refer to baskets. It is striking that this series does not have an observable naturalistic starting point from which the coherent appearance of the urn as a representation of a basket is gradually abstracted, but rather starts off in full development, with idiosyncratic adaptions (e. g., nos. 41 and 42). Furthermore, a clear connection exists between this group (including no. 2), and the above-mentioned representations of cistae mysticae in images. In particular, the horizontal division by means of braided profiles and the arrangement of the wickerwork in vertical registers is a consistent feature that appears on a grave relief in Aquileia ${ }^{75}$, for example, but also in numerous examples from Rome $^{76}$. All these points document the non-arbitrariness of the design and are, above all, evidence of a strong iconographic tradition that spans a long period of time and several media, and functions independently of - or even includes - 'real' wickerwork baskets.

74 Bertacchi 1982, 220; Buora 1982, 189; Monacchi 1996, 971.

75 Scrinari 1972, 106 no. 318; Ortalli 2005, 263f. Fig. 13. Note, however, that the ribs of the wickerwork are diagonal instead of horizontal in this case.

76 Such as in a relief on a rock base in the Villa Albani (Linfert 1998, Pl. 96, 2) and later in Dionysian sarcophagi (Matz 1968, cat. nos. 36. 52), but also in statues, for example on the base of the Farnese bull (Cullin-Mingaud 2010, 63 Fig. 36; La Rocca 1998, 265) or on a comparable new find from the Domus Tiberiana (Abbondanza 2011; 2019). 


\section{Summary}

From the late $1^{\text {st }}$ century onwards, in Rome and Aquileia, stone urns that referred to wickerwork baskets in their surface design were manufactured. The concrete implementation of this reference can be distinguished in different modes that are defined by degrees of proximity to and divergence from basket prototypes, as well as the design principles of urns in general. While most of the urns from Rome engage in a naturalistic representation that replicates the texturing of the basket prototype in vivid detail, they mostly lack links with other urns. However, most of the urns from the Aquileian cluster have been adapted visually to the basket prototypes, mainly by representing the baskets' technologically induced rhythmic surface structure and integrating rather urn-specific features such as tabulae or undecorated lids. There is no doubt that all of these objects are wholly or partly designed to resemble 'real' wicker baskets, which is why they can indeed to some extent be instructive for the study of these (lost) objects. However, it would certainly be a mistake to expect a linear connection in the sense of an individual basket 'original' and a marble or limestone 'copy'. It can be shown on different levels (for example, in the subtle play with design elements in no. 1, or the independent typological seriality with links to the iconography of cistae mysticae in the Aquileian cluster) that the basket urns are clearly part of a design system that includes genre-immanent traditions as well as transmedial connections with basket representations, for example in reliefs or statues.

From an historical perspective, this phenomenon is more than a meaningless fad ${ }^{77}$. It is striking that basket urns were among the very first richly decorated urns in both Rome and Aquileia. They can thus be seen as part of a negotiation process that explored possible design modes for this genre. In Rome, this process also led to various other idiosyncratic solutions ${ }^{78}$, paralleled in Aquileia by attempts to combine figural relief decoration with more or less abstracted wickerwork surfaces (nos. 39-41; Figs. 8 and 9). For a short period, probably limited to the last decades of the $1^{\text {st }}$ century B.C., the basket urn design was therefore one possible way of visually individualising the burial ritual ${ }^{79}$. The subsequent disappearance of the basket urn in Rome concurs with the general decrease in extraordinary urn designs. Thereafter, variations operated more within the limits of the genre's design principles, thus averting blatant visual separation. A similar process occurred in Aquileia with the disappearance of abstract cases, such as nos. 40 and no. 41. Here, however, the basket urn design prevailed as the only mode available for accentuation through decoration.

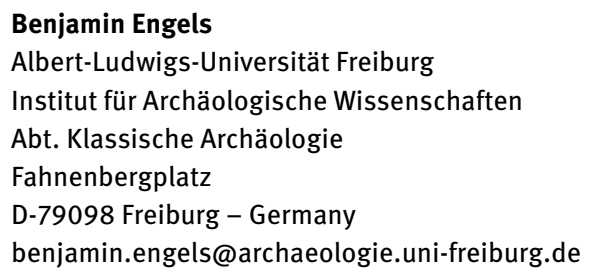

77 As implied by Sinn 1987, 63 and, for pottery, Zimmermann 1998, 143.

78 See Sinn 1987, 22.

79 It should be noted that this explanation in no way excludes a semantic or metaphorical meaning. 


\section{Appendix: List of Basket Urns}

\section{Roman Cluster}

Cylindrical cistae:

1. New York, Metropolitan Museum of Art, inv. 37.129 a, b ${ }^{80}$ (Fig. 5)

Bibliography: Met Collection Online 2020; Zanker 2020, 267 cat. no. 128; Dodero 2019, 453 f. no. 177 Fig. 137; Picón 2007, 364.488 no. 422; La Rocca 1998, 265f. Fig. 57;Cormack 1996; D’Ambra 1989, 399; Sinn 1987, 36 note 253; Mertens 1987, 131 no. 100; Waywell 1986, 106 no. 85 Fig. 31 Pl. 68; Vermeule - Von Bothmer 1959, 150; Alexander 1938, 52 Fig. 3. 2. $\quad$ Rome, Musei Vaticani, Galleria Lapidaria, inv. $9237^{81}$ (Fig. 4)

Bibliography: Liverani et al. 2010, 217 Fig. 180; 222; Sinn 1987, 174 no. 341 Pl. 55 c. e; Verzár Bass 1985, 204; Toynbee 1971, 255; Altmann 1905, 238f. 253 Fig. 198; Amelung 1903, 218 f. no. 74b Pl. 26; Platner et al. 1834, 37 no. 188.

3. Rome, from Porta Maggiore, today lost (Fig. 9)

Bibliography: Broekaert 2008, 205; Petersen 2003, 234. 250 f.; Kleiner 1992, 107; D’Ambra 1989, 399 note 41; Sinn 1987, 63. 274 no. 342; Ciancio Rossetto 1973, 30 note 19 (with 31 Fig. 28); Altmann 1905, 239; Canina 1839, 47 Pl. 4, 11.

Basket chests:

4. Naples, Museo Archeologico Nazionale (Fig. 1)

Bibliography: Cullin-Mingaud 2010, 92; Gostenčnik 2004; Feugère 2001; Gostenčnik 2000, 27; Sinn 1987, 174 f. no. 343 Pl. 55 d.

5. Naples, Museo Archeologico Nazionale Bibliography: Sinn 1987, 175 no. 344 Pl. 55 f.

\section{Aquileian Cluster ${ }^{82}$}

Cylindrical cistae without tabulae, plain lid: 6. Thalheim bei Wels (A), s.n.; 'pseudo-urn' Bibliography: Miglbauer 1994.

7. Graz (A), Schloss Eggenberg, inv. 54; from Ptuj/Poetovio, s. n.; 'pseudo-urn'

Bibliography: Miglbauer 1994, 153. 157; Modrijan - Weber 1979/1981, 97 no. 54.

Cylindrical cista without tabula, sculpted lid (dog):

8. Udine, Museo Civico, s. n.; 'pseudo-urn' Bibliography: Buora 1982, 202 no. 24 Fig. 12.

Cylindrical cistae without tabulae, no lid:

9. Feldkirchen (A), Amthofmuseum, s.n. ${ }^{83}$; 'pseudo-urn'

Bibliography: Gostenčnik 2000a, 63f. Figs. 6. 2; 69 no. 2; 72f.; Piccottini 1996, 77-80 Fig. 31.

10. Rotthof (D), Siebenschläferkirche, spolia; 'pseudo-urn'

Bibliography: Kremer 2001, 145 no. 124; Miglbauer 1994, 153.

Cylindrical cistae, fragments without tabulae:

11. Aquileia, Museo Archeologico, s.n.

Bibliography: Buora 1982, 200 no. 11 Fig. 21.

12. Aquileia, Museo Archeologico, s.n.

Bibliography: Buora 1982, 200 no. 12 Fig. 22.

13. Aquileia, Museo Archeologico, s.n.

Bibliography: Buora 1982, 200 no. 13 Fig. 23.

14. Aquileia, Museo Archeologico, s.n.

Bibliography: Buora 1982, 200 no. 15 Fig. 25.

80 Allegedly found in an Apulian grave context, Dodero 2019, $453 \mathrm{f}$.

81 From Split? Verzár Bass 1985, 204.

82 Buora's catalogue also contains a few single lids that were part of basket urns, Buora 1982, cat. nos. 6-8. These specimens are not listed here, as they (except for some plaited profiles) do not show surface textures resembling wickerwork.

83 From a spoliation context in St. Paul im Lavanttal (A). 
15. Aquileia, Museo Archeologico, s.n.

Bibliography: Buora 1982, 200 no. 16.

16. Aquileia, Museo Archeologico, s.n.

Bibliography: Buora 1982, 201 no. 17.

17. Aquileia, Museo Archeologico, s.n.

Bibliography: Buora 1982, 201 no. 18.

18. Aquileia, Museo Archeologico, s.n.

Bibliography: Buora 1982, 201 no. 19.

19. Aquileia, Museo Archeologico, s. n.; 'pseudo-urn'

Bibliography: Buora 1982, 204 no. 29 Fig. 27.

20. Aquileia, private collection; 'pseudo-urn'

Bibliography: Buora 1982, 205 no. 32 Fig. 16.

21. Invillino, spolia; 'pseudo-urn'

Bibliography: Buora 1982, 206 no. 33 Fig. 18.

Cylindrical cista with tabula, basket lid:

22. Aquileia, Museo Archeologico, s.n. (Fig. 6)

Bibliography: Buora 1982, 198 no. 4 Fig. 5; <http://lupa.at/14468> (30.09.2020).

Cylindrical cistae with tabulae, plain lid:

23. Aquileia, Museo Archeologico, inv. 429

Bibliography: Buora 1982, 197 no. 3 Fig. 4; Maionica 1895, 31 f. no. 20; <http://lupa.at/14461> (30.09.2020).

24. Aquileia, Museo Archeologico, s.n.; 'pseudo-urn'

Bibliography: Buora 1982, 201 no. 21 Fig. 6; <http://lupa.at/14469> (30.09.2020).

25. Aquileia, Museo Archeologico, inv. 583; 'pseudo-urn'

Bibliography: Buora 1982, 203 no. 26 Fig. 14.

26. Aquileia, Museo Archeologico, s. n.; 'pseudo-urn'

Bibliography: Buora 1982, 204 no. 30 Fig. 29.

27. Ljubljana/Emona (SVN), s. n.; 'pseudo-urn'

Bibliography: Plesničar-Gec 1977.

Cylindrical cistae with tabulae, sculpted lid (dog or lion):

28. Aquileia, Museo Archeologico, inv. 854 (Fig. 2)

Bibliography: Giovannini 2010, 201; Buora 1982, 198 no. 5 Fig. 7; Scrinari 1972, 105 no. 315; Bologna 1964/1965, 210 f.

no. 312 Pl. 76, 153; <http://lupa.at/14079> (30.09.2020).

29. Aquileia, Museo Archeologico, inv. 484

Bibliography: Buora 1982, 201 f. no. 22 Fig. 10; Scrinari 1972, 105 no. 316; Brusin 1929, 148 no. 80 Fig. 94; Maionica 1910,

8. 68 no. 141; <http://lupa.at/14472> (30.09.2020).

Cylindrical cista with tabula, pinecone lid:

30. Aquileia, Museo Archeologico, s.n. (Fig. 3)

Bibliography: Bertacchi 1982; <http://lupa.at/14462> (30.09.2020).

Cylindrical cista with tabula, no lid:

31. Aquileia, Museo Archeologico, s.n.

Bibliography: Buora 1982, 199 no. 9 Fig. 19.

32. Aquileia, Museo Archeologico, s.n.

Bibliography: Buora 1982, 199 no. 10 Fig. 20.

33. Aquileia, Museo Archeologico, s.n.

Bibliography: Buora 1982, 200 no. 14 Fig. 24.

34. Tapogliano, Villa Pace, s.n.; 'pseudo-urn'

Bibliography: Buora 1982, 202 no. 23 Fig. 11.

35. Aquileia, Museo Archeologico, s. n.; 'pseudo-urn'

Bibliography: Buora 1982, 202f. no. 25 Fig. 13; Brusin 192958 Fig. 32.

36. Aquileia, Museo Archeologico, s.n.; 'pseudo-urn'

Bibliography: Buora 1982, 204 no. 28 Fig. 26.

37. Aquileia, Museo Archeologico, s.n.; 'pseudo-urn'

Bibliography: Buora 1982, 204 f. no. 31 Fig. 17.

38. Tavagnacco, Villa di Antonio di Prampero, s.n.; 'pseudo-urn'Bibliography: Buora 1999. 
Cylindrical cista with relief decoration

38. Aquileia, Museo Archeologico, inv. 1576; 'pseudorurna' (Fig. 7)

Bibliography: Verzár Bass 2010, 173; Ortalli 2005, 263; Buora 1982, 203f. no. 27 Fig. 15; 39. Beschi 1980, 374 Fig. 341 ; Scrinari 1972, 106 no. 317; Bologna 1964/1965, 210 no. 311 Pl. 76, 152; Brusin 1929, 58 Fig. 31; <http://lupa.at/14004> (30.09.2020).

Cylindrical cista, no basket texture, lacings only:

40. Aquileia, Museo Archeologico, inv. 1581

Bibliography: Buora 1982, 196f. no. 2 Fig. 3; <http://lupa.at/14463> (30.09.2020).

Cylindrical cista, no basket texture, lacings only, with relief decoration

41. Aquileia, Museo Archeologico, inv. 317 (Fig. 8)

Bibliography: Verzár Bass 2010, 174 f.; Ortalli 2005, 264f. Fig. 14; Buora 1982, 195f. no. 1 Fig. 1; Beschi 1980, 374 Figs. 342-345; Scrinari 1972, 106f. no. 322; Brusin 1964, 161 f. Fig. 94; Brusin 1929, 130 f. no. 52 Fig. 83; Maionica 1910, 48f. no. $101<$ http://lupa.at/13938> (30.09.2020).

Round lid with basket texture:

42. Aquileia, Museo Archeologico, s.n.

Bibliography: Buora 1982, 201 no. 20 Fig. 30.

Basket chest, lid fragment:

43. Teurnia, today lost

Bibliography: Gostenčnik 2000; Gostenčnik 2000a, 69-72 no. 1; Glaser 1997, 31 no. 11 Pl. 8, 11.

\section{Illustration Credits}

Fig. 1: After Sinn 1987, Pl. 55 d.

Fig. 2: Aquileia, Museo Archeologico, inv. 854. ( ) Friuli Venezia Giulia - Soprintendenza per i Beni Archeologici.

Fig. 3: Aquileia, Museo Archeologico, s. n. @ Friuli Venezia Giulia - Soprintendenza per i Beni Archeologici.

Fig. 4: After Sinn 1987, Pls. 55 c. e.

Fig. 5: New York, Metropolitan Museum of Art, inv. 37.129 a, b., CC0 1.0 Universal (CC0 1.0) Public Domain Dedication.

Fig. 6: Aquileia, Museo Archeologico, s.n. (c) Friuli Venezia Giulia - Soprintendenza per i Beni Archeologici.

Fig. 7: Aquileia, Museo Archeologico, inv. 1576. ( ) Friuli Venezia Giulia - Soprintendenza per i Beni Archeologici. Fig. 8: Aquileia, Museo Archeologico, inv. 317. ( Friuli Venezia Giulia - Soprintendenza per i Beni Archeologici.

Fig. 9: After Canina 1839, Pl. 4, 11.

Fig. 10: After Dräger 1994, Pl. 77, 2.

\section{Bibliography}

Abbondanza 2011: L. Abbondanza, Le sculture, in: M. A. Tomei (ed.), Domus Tiberiana. Scavi e restauri, 1990-2011 (Milan 2011) 274-287

Abbondanza 2019: L. Abbondanza, Frammenti di una cista mystica in marmo dal Criptoportico della Domus Tiberiana, in: M. de Souza - O. Devillers (eds.), Neronia X. Le Palatin. Émergence de la colline du pouvoir à Rome, de la mort d’Auguste au règne de Vespasien, 14-79 p. C., Mémoires 55 (Bordeaux 2019) 91-107

Alexander 1938: C. Alexander, Recent Accessions in the Greek and Roman Department, Bulletin of the Metropolitan Museum of Art 33, 2, 1938, 50-52

Altmann 1905: W. Altmann, Die römischen Grabaltäre der Kaiserzeit (Berlin 1905)

Amelung 1903: W. Amelung, Die Sculpturen des Vaticanischen Museums I (Berlin 1903)

Bertacchi 1982: L. Bertacchi, Urna cineraria di recente rinvenimento, AquilNost 53, 1982, 217-228

Beschi 1980: L. Beschi, Le arti plastiche, in: B. Forlati Tamaro (ed.), Da Aquileia a Venezia. Una mediazione tra l'Europa e l'Oriente dal II secolo a.C. al VI secolo d.C. (Milan 1980) 337-449

Bezeczky 2013: T. Bezeczky, The Amphorae of Roman Ephesus, FiE 15, 1 (Vienna 2013) 
Blitz 2015: J. H. Blitz, Skeuomorphs, Pottery, and Technological Change, American Anthropologist 117, 4, 2015 , 665-678

Bologna 1964/1965: Arte e civiltà romana nell'Italia settentrionale dalla repubblica alla tetrarchia. 20 settembre 22 novembre 1964, Bologna, Palazzo dell'Archiginnasio (Bologna 1964/1965)

Brann 1962: E. T. H. Brann, Late Geometric and Protoattic Pottery. Mid $8^{\text {th }}$ to Late $7^{\text {th }}$ Century B.C., Agora 8 (Princeton 1962)

Broekaert 2008: W. Broekaert, "Bread Baskets on the Marketplace"? A Short Note on CIL IX 2854 (ILS 5591), ZPE 167, 2008, 204-206

Brusin 1929: G. Brusin, Aquileia. Guida storica e artistica (Udine 1929)

Brusin 1964: G. Brusin, Aquileia e Grado. Guida storico-artistica 5 (Padova 1964)

Buora 1982: M. Buora, Urne e pseudourne a cista aquileiesi, AquilNost 53, 1982, 189-208

Buora 1999: M. Buora, Una nuova pseudourna a cista (da Aquileia?) nella villa di Antonino di Prampero a Tavagnacco, AquilNost 70, 1999, 145-147

Canina 1839: L. Canina, Descrizione del luogo denominato anticamente La speranza vecchia, del monumento delle acque Claudia ed Aniene nuova e del sepolcro di Marco Vergilio Eurisace (Rome 1839)

Ciancio Rossetto 1973: P. Ciancio Rossetto, Il sepolcro del fornaio Marco Virgilio Eurisace a Porta Maggiore I, Monumenti romani 5 (Rome 1973)

Coates-Stephens 2004: R. Coates-Stephens, Porta Maggiore. Monument and Landscape. Archaeology and Topography of the Southern Esquiline from the Late Republican Period to the Present, BCom Suppl. 12 (Rome 2004)

Colley March 1890: H. Colley March, The Meaning of Ornament. Or its Archaeology and its Psychology, Transactions of the Lancashire and Cheshire Antiquarian Society 7, 1890, 160-191

Cormack 1996: S. H. Cormack, Cinerary Urn in the Form of a Basket, in: D. E. E. Kleiner - S. B. Matheson (eds.), I, Claudia. Women in Ancient Rome, Exhibition Catalogue New Haven (Austin, TX 1996) 202 no. 153

Cullin-Mingaud 2010: M. Cullin-Mingaud, La vannerie dans l'Antiquité romaine. Les ateliers de vanniers et les vanneries de Pompéi, Herculaneum et Oplontis (Naples 2010)

D’Ambra 1989: E. D’Ambra, The Cult of Virtues and the Funerary Relief of Ulpia Epigone, Latomus 48, 1989, 392-400

Dodero 2019: E. Dodero, Ancient Marbles in Naples in the Eighteenth Century. Findings, Collections, Dispersals, Studies in the History of Collecting \& Art Markets 7 (Leiden 2019)

Donohue 2005: A. A. Donohue, Greek Sculpture and the Problem of Description (Cambridge 2005)

Dorka Moreno 2019: M. Dorka Moreno, Imitatio Alexandri? Ähnlichkeitsrelationen zwischen Götter- sowie Heroenbildern und Porträts Alexanders des Großen in der griechisch-römischen Antike, Tübinger Archäologische Forschungen 29 (Rahden 2019)

Dräger 1994: O. Dräger, Religionem significare. Studien zu reich verzierten römischen Altären und Basen aus Marmor, RM Suppl. 33 (Mainz 1994)

Feugère 2001: M. Feugère, Cistes en osier à verrou d'os, Instrumentum 14, 2001, 24-26

Fullerton 1997: M. D. Fullerton, Imitation and Intertextuality in Roman Art, JRA 10, 1997, 427-440

Ganzert 1983: J. Ganzert, Zur Entwicklung lesbischer Kymationformen, JdI 98, 1983, 123-202

Gill - Vickers 1990: D. W. J. Gill - M. Vickers, Reflected Glory. Pottery and Precious Metals in Classical Greece, Jdl 105, 1990, 1-30

Giovannini 2010: A. Giovannini, I rituali dell'addio, in: L. Fozzati (ed.), Aquileia. Patrimonio dell'umanità (Udine 2010) 191-217

Glaser 1997: F. Glaser, Die Skulpturen des Stadtgebiets von Teurnia, CSIR Österreich 2, 6 (Vienna 1997)

Golda 1997: T. M. Golda, Puteale und verwandte Monumente. Eine Studie zum römischen Ausstattungsluxus, Beiträge zur Erschließung hellenistischer und kaiserzeitlicher Skulptur und Architektur 16 (Mainz 1997)

Gostenčnik 1997: K. Gostenčnik, Beinscheiben als Zentren von Deckeln und Böden geflochtener Behälter?, Instrumentum 6, 1997, 13

Gostenčnik 2000: K. Gostenčnik, Eine frühkaiserzeitliche Flechtwerkurne aus Teurnia in Kärnten (Österreich), Instrumentum 14, 2001, $26 \mathrm{f}$.

Gostenčnik 2000a K. Gostenčnik, Flechtwerk und Korbwaren im römischen Kärnten, Carinthia I 191, 2001, 53-74

Gostenčnik 2004: K. Gostenčnik, Die Versiegelung römischer Flechtwerkbehälter, Carinthia I 194, 2004, 713-716

Grüner 2017: A. Grüner, Schönheit und Massenproduktion. Die Ästhetik der Terra Sigillata, in: M. Flecker (ed.), Neue Bilderwelten. Zu Ikonographie und Hermeneutik italischer Sigillata. Kolloquium vom 16.-18. April 2015 in Tübingen, Tübinger Archäologische Forschungen 23 (Rahden 2017) 25-35

Haddon 1895: A. C. Haddon, Evolution in Art. As Illustrated by the Life-Histories of Designs (London 1895)

Haug 2018: A. Haug, Ornament und Design. Attisch geometrische Figuralgefäße und Gefäße mit plastischem Dekor, in: N. Dietrich - M. Squire (eds.), Ornament and Figure in Graeco-Roman Art. Rethinking Visual Ontologies in Classical Antiquity (Berlin 2018) 97-127 
Jones 2018: N. B. Jones, Exemplarity and Encyclopedism at the Tomb of Eurysaces, ClAnt 37, 2018, 63-107

Kleiner 1992: D. E. E. Kleiner, Roman Sculpture (New Haven, CT 1992)

Krauskopf 2005: ThesCRA V (2005) 274-278 s. v. Kiste, cista (I. Krauskopf)

Kremer 2001: G. Kremer, Antike Grabbauten in Noricum. Katalog und Auswertung von Werkstücken als Beitrag zur Rekonstruktion und Typologie, Sonderschriften des Österreichischen Archäologischen Instituts 36 (Vienna 2001)

La Rocca 1998: E. La Rocca, Artisti rodii negli horti romani, in: M. Cima - E. La Rocca (eds.), Horti romani. Atti del convegno internazionale, Roma, 4-6 maggio 1995, BCom Suppl. 6 (Rome 1998) 203-274

Lattimore 1942: R. Lattimore, Themes in Greek and Latin Epitaphs (Urbana, IL 1942)

Linfert 1998: A. Linfert, Felsbasis einer Brunnenfigur, in: P. C. Bol - A. Allroggen-Bedel (eds.), Forschungen zur Villa Albani. Katalog der antiken Bildwerke V. In den Gärten oder auf Gebäuden aufgestellte Skulpturen sowie die Masken (Berlin 1998) 247-251 no. 733

Lipps 2011: J. Lipps, Die Basilica Aemilia am Forum Romanum. Der kaiserzeitliche Bau und seine Ornamentik, Palilia 24 (Wiesbaden 2011)

Liverani u. a. 2010: P. Liverani - G. Spinola - P. Zander, Die Nekropolen im Vatikan (Stuttgart 2010)

Maionica 1895: H. Maionica, Nachrichten über das k. k. Staats-Museum in Aquileja, Mitteilungen der K. K. Zentral-Kommission zur Erforschung und Erhaltung der Kunst- und Historischen Denkmale 21, 1895, 30-33

Maionica 1910: H. Maionica, Führer durch das K. K. Staatsmuseum in Aquileia (Vienna 1910)

Matz 1968: F. Matz, Die dionysischen Sarkophage, ASR 4 (Berlin 1968)

Mertens 1987: J. R. Mertens (ed.), The Metropolitan Museum of Art. Greece and Rome (New York 1987)

Met Collection Online 2020 Met Collection Online, Marble Cinerary Urn with Lid, <https://www.metmuseum.org/art/ collection/search/253553> (30.09.2020)

Miglbauer 1994: R. Miglbauer, Ein römerzeitlicher Grabaufsatz aus Thalheim bei Wels (Oberösterreich), AquilNost $65,1994,149-160$

Modrijan - Weber 1979/1981: W. Modrijan - E. Weber, Die Römersteinsammlung des Johanneums im Eggenberger Schloßpark. 2. Teil. Verwaltungsbezirke Virunum, Ovilava, Celeia und Poetovio, Schild von Steier 14, 1979/1981, 7-107

Monacchi 1996: D. Monacchi, Un vitor e l'artigianato della cestineria ad Ameria, MEFRA 108, 1996, 943-977

Ortalli 2005: J. Ortalli, Simbolo e ornato nei monumenti sepolcrali romani. Il caso aqilieiese, in: G. Cuscito - M. Verzár Bass (eds.), Aquileia dalle origini alla costituzione del ducato longobardo. La cultura artistica en età romana (II secolo a.C. - III secolo d.C.). Atti della 35. settimana di Studi Aquileiesi 6-8 maggio 2004, Antichità altoadriatiche 61 (Trieste 2005) 245-286

Petersen 2003: L. H. Petersen, The Baker, His Tomb, His Wife, and Her Breadbasket. The Monument of Eurysaces in Rome, ArtB 85, 2003, 230-257

Pfanner 1983: M. Pfanner, Der Titusbogen. Beiträge zur Erschließung hellenistischer und kaiserzeitlicher Skulptur und Architektur II (Mainz 1983)

Piccottini 1996: G. Piccottini, Archäologische Mitteilungen aus Kärnten VI, Carinthia I 186, 1996, 51-95

Picón 2007: C. A. Picón, Art of the Classical World in the Metropolitan Museum of Art. Greece, Cyprus, Etruria, Rome (New Haven, CT 2007)

Platner et al. 1834: E. Platner - C. Bunsen - E. Gerhard - W. Röstell, Beschreibung der Stadt Rom II. Das vaticanische Gebiet und die vaticanischen Sammlungen (Stuttgart 1834)

Plesničar-Gec 1977: L. Plesničar-Gec, Nova napisa iz Emone. Altre due epigrafi emoniensi, AVes 28, 1977, $117 \mathrm{f}$.

Rajewsky 2002: I. O. Rajewsky, Intermedialität (Tübingen 2002)

Rolley 2001: C. Rolley, Rev. of N. Zimmermann, Beziehungen zwischen Ton- und Metallgefäßen spätklassischer und frühhellenistischer Zeit, Internationale Archäologie 20 (Rahden 1998), Gnomon 73, 2001, 368 f.

von Rosen 2011: U. Pfisterer (ed.), Metzler Lexikon Kunstwissenschaft. Ideen, Methoden, Begriffe ${ }^{2}$ (Stuttgart 2011) 208-211 s.v. Interpikturalität (V. von Rosen)

Scrinari 1972: V. S. M. Scrinari, Museo Archeologico di Aquileia. Catalogo delle sculture romane. Exhibition Catalogue Aquileia (Rome 1972)

Semper 1863: G. Semper, Der Stil in den technischen und tektonischen Künsten, oder praktische Ästhetik. Ein Handbuch für Techniker, Künstler und Kunstfreunde 2. Keramik, Tektonik, Stereotomie, Metallotechnik (Munich 1863)

Sinn 1987: F. Sinn, Stadtrömische Marmorurnen, BeitrESkAr 8 (Mainz 1987)

Strässle 2014: T. Strässle, Einleitung. Pluralis materialitatis, in: T. Strässle - C. Kleinschmidt - J. Mohs (eds.), Das Zusammenspiel der Materialien in den Künsten. Theorien - Praktiken - Perspektiven (Bielefeld 2014) 7-23

Toynbee 1971: J. M. C. Toynbee, Death and Burial in the Roman World (London 1971)

Vermeule - Von Bothmer 1959: C. Vermeule - D. von Bothmer, Notes on a New Edition of Michaelis. Ancient Marbles in Great Britain 3, 1, AJA 63, 1959, 139-166

Verzár Bass 1985: M. Verzár Bass, Rapporti tra l'Alto Adriatico e la Dalmazia. A proposito di alcuni tipi di monumenti funerari, in: Aquileia, la Dalmazia e l'Illirico. Atti della 14 settimana di studi aquileiesi, 23-29 aprile 1983 (Udine 1985) 183-208 
Verzár Bass 1998: M. Verzár Bass, Grab und Grabsitte in Aquileia, in: P. Fasold (ed.), Bestattungssitte und kulturelle Identität. Grabanlagen und Grabbeigaben der frühen römischen Kaiserzeit in Italien und den NordwestProvinzen. Kolloquium in Xanten vom 16. bis 18. Februar 1995 (Cologne 1998) 143-180

Verzár Bass 2010: M. Verzár Bass, La città dei morti, in: L. Fozzati (ed.), Aquileia. Patrimonio dell'umanità (Udine 2010) 172-190

Vickers 1985: M. Vickers, The Influence of Metal Work on Athenian Painted Pottery, JHS 105, 1985, 108-128

Vickers 1999: M. Vickers, Skeuomorphismus oder die Kunst, aus wenig viel zu machen, TrWPr 16 (Mainz 1999)

Wabersich 2014: H. Wabersich, Form und Medium. Überlegungen zu materialübergreifenden Gefäßformen antiken Tafelgeschirrs, in: D. Graen - M. Rind - H. Wabersich (eds.), Otium cum dignitate. Festschrift für Angelika Geyer zum 65. Geburtstag. Studien zur Archäologie und Rezeptionsgeschichte der Antike, BARIntSer 2605 (Oxford 2014) 209-226

Waywell 1986: G. B. Waywell, The Lever and Hope Sculptures. Ancient Sculptures in the Lady Lever Art Gallery. Port Sunlight and a Catalogue of the Ancient Sculptures Formerly in the Hope Collection. London and Deepdene, CSIR Great Britain 3, 1 (Berlin 1986)

Wegner 1957: M. Wegner, Ornamente kaiserzeitlicher Bauten Roms. Soffitten (Cologne 1957)

Wessels 2014: A. Wessels, Zwischen Illusion und Distanz. Zur Wirkungsästhetik lebensechter Gegenstände, in: R. Bielfeldt (ed.), Ding und Mensch in der Antike. Gegenwart und Vergegenwärtigung (Heidelberg 2014) 275-300

Wirth 2013: U. Wirth, Intermedialität, in: T. Anz (ed.), Handbuch Literaturwissenschaft. Gegenstände - Konzepte Institutionen (Stuttgart 2013) 254-264

Wolf 2016: G. Wolf, Vesting Walls, Displaying Structure, Crossing Cultures. Transmedial and Transmaterial Dynamics of Ornament, in: G. Necipoğlu - A. Payne (eds.), Histories of Ornament. From Global to Local (Princeton, NJ 2016) 96-105

Wolf 2019: G. Wolf, Die Vase und der Schemel. Ding, Bild oder eine Kunstgeschichte der Gefässe, Connecting Art Histories in the Museum 4 (Dortmund 2019)

Zanker 2020: P. Zanker, Tombs and Funerary Monuments, in: P. Zanker - S. A. Hemingway - C. S. Lightfoot - J. R. Mertens (eds.), Roman Art. A Guide Through the Metropolitan Museum of Art's Collection (New York 2020) 260-293

Zimmermann 1998: N. Zimmermann, Beziehungen zwischen Ton- und Metallgefäßen spätklassischer und frühhellenistischer Zeit, Internationale Archäologie 20 (Rahden 1998) 
